\title{
Impacts of Marine Heatwaves on Algal Structure and Carbon Sequestration in Conjunction With Ocean Warming and Acidification
}

\author{
Guang Gao*, Xin Zhao, Meijia Jiang and Lin Gao \\ State Key Laboratory of Marine Environmental Science and College of Ocean and Earth Sciences, Xiamen University, \\ Xiamen, China
}

OPEN ACCESS

Edited by:

Peng Jin

University of Guangzhou, China

Reviewed by:

Laura Sordo,

Portuguese Institute for Sea and Atmosphere (IPMA), Portugal

Douglas Andrew Campbell,

Mount Allison University, Canada

*Correspondence: Guang Gao

guang.gao@xmu.edu.cn

Specialty section:

This article was submitted to Global Change and the Future Ocean,

a section of the journal

Frontiers in Marine Science

Received: 14 August 2021 Accepted: 02 September 2021 Published: 23 September 2021

Citation:

Gao G, Zhao X, Jiang $M$ and Gao L (2021) Impacts of Marine

Heatwaves on Algal Structure

and Carbon Sequestration in Conjunction With Ocean Warming and Acidification.

Front. Mar. Sci. 8:758651. doi: 10.3389/fmars.2021.758651
As the ocean warms, the frequency, duration, intensity, and range of marine heatwaves (MHWs) increase. MHWs are becoming a severe challenge for marine ecosystems. However, our understanding in regard to their impacts on algal structure and carbon sequestration is still deficient or fragmentary, particularly when combined with ocean warming and acidification. In this paper, we reviewed the impacts of MHWs individually and combined with ocean warming and acidification on regime shift in algal community and carbon sequestration of both macroalgae and microalgae. Solid evidence shows that MHWs cause the decline of large canopy macroalgae and increase of turf-forming macroalgae in abundance, leading to the regime shift from kelp forests to seaweed turfs. Furthermore, increased grazing pressure on kelps due to tropicalization facilitates the expansion of turfs that prevent the recovery of kelps through plundering light and space. Meanwhile, MHWs could trigger microalgal blooms and the intensity of algal blooms is regulated by the severity of MHWs and nutrient availability. MHWs could lead to the decrease of carbon burial and sequestration by canopy-forming macroalgae due to depressed growth and increased mortality. The effects of MHWs on the productivity of microalgae are latitude-dependent: negative effects at low and mid-latitudes whilst positive effects at high latitudes. Ocean warming and acidification may accelerate the shift from kelps to turfs and thus decrease the carbon sequestration by canopy-forming macroalgae further. We propose that MHWs combined with ocean warming and acidification would reduce the biodiversity and facilitate the thriving of morphologically simple, ephemeral and opportunistic turfs and diatoms in coastal oceans, and phytoplankton with smaller size in open oceans. This structure shift would not be in favor of long-term carbon sequestration. Future studies could be conducted to test this hypothesis and investigate the impacts of MHWs on carbon sequestration under future ocean conditions.

Keywords: algal bloom, biodiversity, heatwave, carbon sequestration, ocean acidification, ocean warming, algae, seaweed

\section{INTRODUCTION}

The term of marine heatwaves (MHWs) was first proposed by Pearce et al. (2011) although the variability of sea surface temperature (SST) has been studied for decades in physical oceanography and climate science (Philander, 1983). MHWs are anomalous warming events that can substantially affect marine ecosystems. The common accepted definition for MHWs is daily temperatures above 
90\% threshold during a 30-year historical baseline period and lasting at least 5 days (Hobday et al., 2016). MHWs can last from a few days to several months even a year, and can reach thousands of kilometers (Scannell et al., 2016). MHWs are driven by multiple factors, including air-sea heat fluxes, ocean heat advection, large-scale climate variability, etc. (Oliver et al., 2020). It was found that from 1925 to 2016, global average frequency and duration of MHWs increased by 34 and 17\%, respectively, resulting in a 54\% increase in annual marine heatwave days globally (from 26 to 40 days). Furthermore, these trends are largely driven by increases in mean ocean temperatures, suggesting that further increases in marine heatwave days can be expected under the context of global warming (Oliver et al., 2018; Benthuysen et al., 2020).

Since the start of the industrial revolution, humans have greatly increased fossil fuel burning and released unprecedented amount of $\mathrm{CO}_{2}$ into the atmosphere, increasing the $\mathrm{CO}_{2}$ concentration of atmosphere from 280 ppmv before industrialization to $417 \mathrm{ppmv}$ by July 2021 (NOAA, 2021). Atmospheric $\mathrm{CO}_{2}$ level is still rising with an approximate rate of 2 ppmv per year (NOAA, 2021). The accumulation of atmospheric $\mathrm{CO}_{2}$ together with other greenhouse gasses including water vapor, ozone, methane and nitric oxide adds to greenhouse effect, leading to global warming. Human activities have caused about $1^{\circ} \mathrm{C}$ rise from the pre-industrial period, with a putative range of $0.8-1.21^{\circ} \mathrm{C}$ (IPCC, 2013). Ocean, as a big carbon sink, has absorbed approximately one third of $\mathrm{CO}_{2}$ emitted by humans, which, on the other hand, leads to $\mathrm{pH}$ decrease termed as ocean acidification (Gao et al., 2012; IPCC, 2013). Ocean warming and acidification are recognized as two major anthropogenic perturbations of today's oceans (Schlüter et al., 2014). They are also two most related global variables to MHWs and their combined effects with MHWs are gaining concerns in recent years (Figure 1).

Marine algae, classified as microalgae and macroalgae, are the key primary producers for marine ecosystems. They supply basic materials and energy for other consumers and therefore play an essential role in maintaining marine ecosystems. Marine algae are the main contributor to marine primary productivity and they contributed about half of $\mathrm{O}_{2}$ production and $\mathrm{CO}_{2}$ uptake on the earth, playing an essential role in carbon sequestration and relieving climate change (Falkowski et al., 1998; Raven, 2017). On the other hand, rapid growth and biomass accumulation of some algae species in large scale can form algal blooms, including both microalgal blooms and macroalgal blooms. These blooms can alter algal structure and reduce algal diversity. More importantly, they can significantly impact marine environment, leading to acidification and deoxygenation, causing the death of animals due mainly to the toxins they excreted and thereby disturbing marine ecosystems (Gao et al., 2016; Sakamoto et al., 2021). Therefore, algal diversity is an essential index for a healthy ecosystem. In spite of the importance of algal diversity and carbon sequestration, our understanding on the impacts of MHWs on them is still fragmentary, particularly when combined with ocean warming and acidification. In this study, we first reviewed how MHWs affect algal structure and diversity, and then assessed the impacts of MHWs on algal carbon sequestration. Given the close connection between MHWs and ocean warming/acidification, the combined effects of them were also reviewed. Both macroalgae and microalgae are involved in the present study.

\section{BIBLIOMETRIC ANALYSIS}

We searched the literature through Web of Science in July 2021 with the keywords of "heatwave" AND "algae" OR "seaweed" and as a result 66 articles were found. In the present study, we aimed to investigate the impacts of MHWs alone and their combination with ocean warming/acidification, and thus tried to avoid those only focusing on ocean warming and/acidification. To illuminate the research gap and evaluate trends of MHWs on algae, bibliometric analysis was conducted with VOSviewer 1.6.17. Bibliometric maps of hot keywords and co-authorship in different countries in 66 articles were built. The minimum number of occurrences of a keyword is three and the minimum number of documents of a country is set as one.

\section{IMPACTS OF MARINE HEATWAVES}

\section{Algal Structure Structure Shift of Macroalgae Under Marine Heatwaves}

Macroalgae are indispensable components for coastal ecosystems, serving as nurseries and shelters for marine animals. They are especially critical for local communities because they directly modify the ambient environment and influence adjacent habitats (Wernberg et al., 2018). They often dominate shallowwater rocky ecosystems and play an essential role in carbon sequestration and cycle (Ortega et al., 2019). In addition, macroalgae are important marine resources, supplying food, feed, medicine and biofuels for humans (Gao et al., 2018a, 2020). Therefore, the impacts of MHWs on macroalgae raise wide concerns.

Field observations show that MHWs could lead to the decline of large canopy macroalgae in abundance. MHWs in Western Australia led to the lack of seasonality in growth rates and high rates of mortality for crustose coralline algae (Short et al., 2015). Bull kelp (Nereocystis luetkeana) forests, historically resilient to fluctuating environmental conditions, experienced unprecedented losses along $350 \mathrm{~km}$ of coastline in northern California due to the extreme marine heatwaves between 2014 and 2016, and the once extensive giant kelp forests have not recovered till now (McPherson et al., 2021). Therefore, the multiple-year MHWs lead to a persistently altered ecosystem state with low primary productivity. Furthermore, all bull kelps (Durvillaea spp.) were eliminated from Pile Bay in the South Island of New Zealand due to the MHWs during the summer of 2017/18 (Thomsen et al., 2019).

Meanwhile, some species are resistant to MHWs. For instance, it was demonstrated that the MHWs in 2014-2015 did not significantly change the community structure of kelp forests, particularly the biomass of giant kelp Macrocystis pyrifera in 


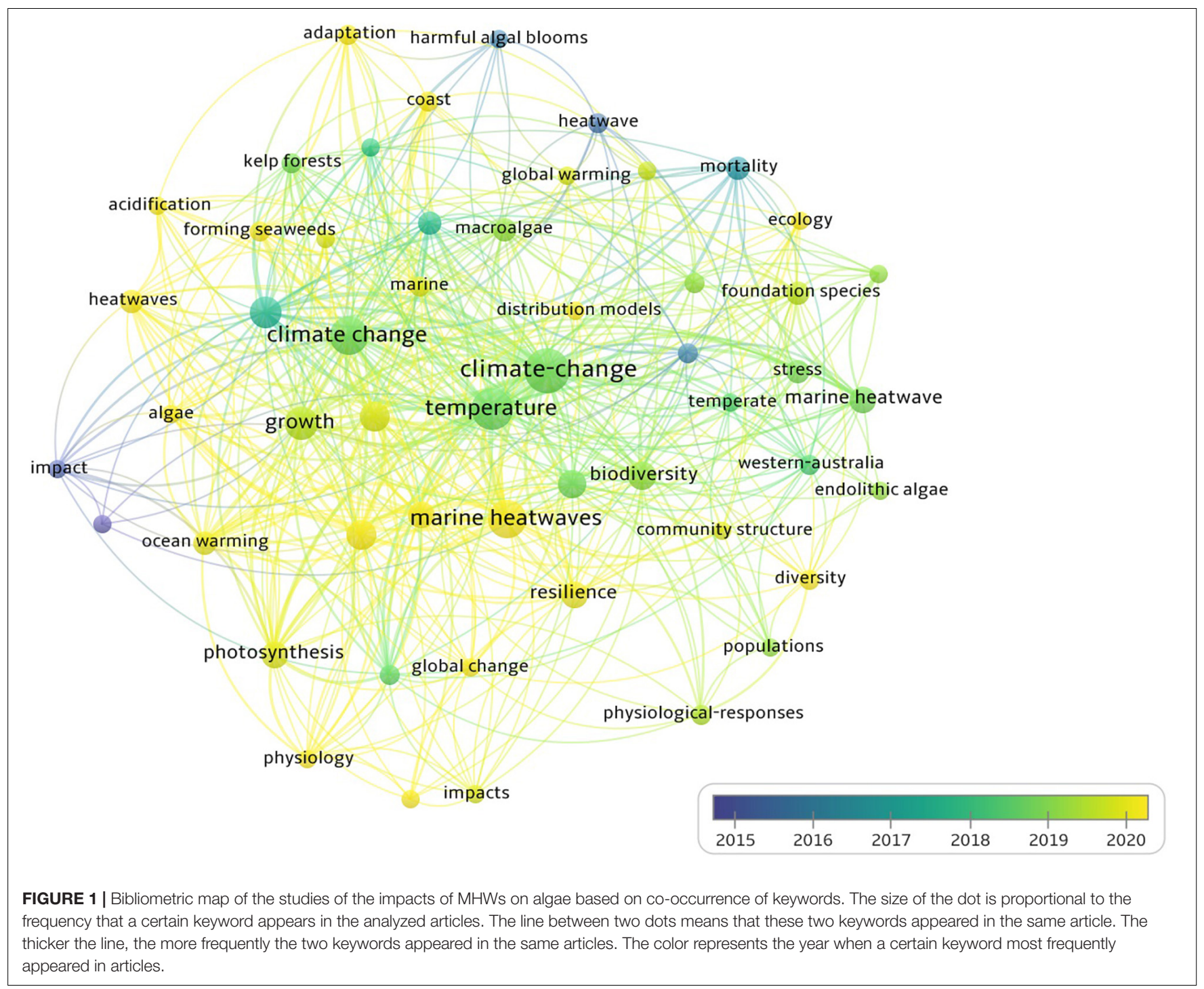

southern California (Reed et al., 2016) and constant average carbonate production rates of coralline algae from Western Australia during marine heatwave events (Dee et al., 2021). Furthermore, MHWs in the South Island of New Zealand promoted the recruitment of the invasive kelp Undaria pinnatifida and green sheet-forming Ulva spp. (Thomsen et al., 2019). In the southern Mexican Pacific coral reef communities, algal cover (mainly turf macroalgae) increased from 2.4 to $6.1 \%$ during a warming event associated with the 2009-2010 El Ni ño (López-Pérez et al., 2016). A dramatic increase in the cover of turf-forming seaweeds was also found in southwestern Australia following the 2010/11 MHWs, leading to a regime shift from kelp forests to seaweed turfs (Smale and Wernberg, 2013; Wernberg et al., 2016). In addition, simulated summer MHWs reduced growth rates of native seaweeds (Fucus serratus and Chondrus crispus) while increased growth rates of Sargassum muticum. Similarly, simulated MHWs reduced the maximum quantum yield of PSII of Fucus serratus and Chondrus crispus in both winter and summer but did not affect it in winter and even promoted it in summer for Sargassum muticum (Atkinson et al., 2020).

\section{Factors Driving the Alteration of Macroalgal Structure}

The differential impacts of MHWs on macroalgae first could be attributed to species differences. Most canopy-forming seaweed species are adapted to cool and nutrient-rich waters and thus are vulnerable to ocean warming and MHWs (Fernandez, 2011; Straub et al., 2019). Warming will reduce their growth, and weaken their response to other perturbations such as grazing, competition, epiphytes, and mechanical damage (Simonson et al., 2015). On the other hand, turf macroalgae tend to be small, opportunistic species with high growth and turnover rates that can be highly stress tolerant compared with larger canopyforming macroalgae (Airoldi, 1998). Location or background temperature is another factor affecting algal response to MHWs. In contrast to the collapse of most kelp forests after experiencing MHWs, kelp forests in the center and cooler ends of their species' distributions are usually resilient to MHWs. For instance, a recent 
large-scale warming event in the North Pacific Ocean did not result in a large change of the community structure of kelp forests in southern California (Reed et al., 2016). The possible explanation is that southern California does not represent either the geographical or thermal limit for the giant kelp Macrocystis pyrifera in the northeast Pacific (Graham et al., 2007). Different nutrient utilization strategies may also contribute to the shift from kelps to turfs. Turfs have high nutrient uptake and can rapidly take up the available nutrients and proliferate under replete nutrient conditions (Hein et al., 1995). By comparison, canopy-forming kelps tend to store available nutrients in their tissue and maintain relatively consistent growth rates under changing environments (Lobban and Harrison, 1994). These differences enable turfs to outcompete kelps and rapidly occupy available space when nutrient availability is high (Gorman et al., 2009). Although higher nitrate level could ameliorate the negative impacts of MHWs on growth and photosynthesis of kelps (Fernández et al., 2020), it is not enough to compete with fastgrowing turfs. The presence of turfs could inhibit the recruitment of kelps and therefore lead to a comprehensive loss of kelps (Connell et al., 2008; Connell and Russell, 2010).

In addition to bottom-up effects, biological factors also drive loss of canopy-forming macroalgae and thriving of turfs. Some invertebrates, crustaceans and fish feed on kelp can result in the decline of kelp biomass and enhancing fragmentation and breakage of kelp through grazing (Krumhansl et al., 2011; Zarco-Perello et al., 2017). Another organism that prefers to graze erect macroalgae is sea urchins. Altered environment conditions and the removal of top predators trigger blooms of sea urchin that drives regime shifts from kelp forests to coralline algal-dominated "barrens" (Filbee-Dexter et al., 2016). MHWs can induce poleward range shifts of subtropical and tropical herbivores, leading to increased grazing pressure (Zarco-Perello et al., 2017). A substantial influx of tropical fish herbivores can lead to a $400 \%$ increase in grazing rates compared to healthy coral reefs (Filbee-Dexter and Wernberg, 2018). This enhanced grazing pressure facilitates the shift from kelps to turfs and prevents the recovering of kelp forests (Bennett et al., 2015). In addition, rising temperatures could increase the recruitment and growth of epiphytes that coat the kelp blades. Overgrowth of these epiphytes reduces the strength of the kelp tissue, promotes breakage and canopy loss and hence contributes to shifts to turfs (Andersen et al., 2011; Filbee-Dexter and Scheibling, 2012). In contrast, turfs have a higher tolerance to high temperatures compared to their grazers, indicating decreased grazing pressure under MHWs (Mertens et al., 2015). The bottom-up and top-down may impose synergistic effects on the shift from kelps to turfs.

\section{Microalgal Bloom During Marine Heatwaves}

Microalgae usually occur in low concentrations due mainly to nutrient limitation. However, concentrations of microalgae could also reach very high levels in coastal waters where nutrient availability is high, termed red tides or brown tides. Among 5,000 + microscopic algae species existing worldwide, about 300 species can cause high concentrations of red tides, including toxic species in dinofagellates, diatoms, Haptophyceae, and Cyanophyceae (Zohdi and Abbaspour, 2019), in which the pelagophyte Aureococcus anophagefferens is the key causative species for brown tides (Tang et al., 2019).

Compared to macroalgae, impacts of MHWs on microalgae are less studied (Figure 1). A noteworthy phenomenon is that MHWs usually induce microalgal blooms. In 2013, MHWs in South Australia experienced unusually high and variable water temperatures $\left(5^{\circ} \mathrm{C}\right.$ above the historic average), lasted for 1 week and led to the algal bloom dominated by a harmful diatom, Chaetoceros coarctatus (Roberts et al., 2019). C. coarctatus could be the dominant species because it is tolerant to high temperature (Hasle and Syvertsen, 1997). Extreme MHWs could lead to extreme HABs. In late spring 2015, an unprecedented bloom of chain-forming diatom Pseudo-nitzschia australis occurred along the west coast of North America, spanning from central California to at least as far north as British Columbia during the multiple-year MHWs "blob" (Trainer et al., 2020). Pseudonitzschia australis has high heat-tolerant and affinity of nitrate and ammonium (Cochlan et al., 2008) that provides this species with a competitive advantage for acquiring nitrogen $(\mathrm{N})$ under N-depleted conditions (Kudela et al., 2010). Pseudo-nitzschia australis is a toxic diatom that produces biotoxin domoic acid (DA). This harmful algal bloom generated the highest particulate concentrations of DA ever recorded in Monterey Bay, California (Ryan et al., 2017) and DA was detected in many animalsincluding porpoises, whales, dolphins, sea lions, seals, and seabirds-spanning the largest geographic extent ever recorded (McCabe et al., 2016). DA can cause illness and mortality of marine organisms and threaten human health through food chain transfer. Therefore, the outbreak of HAB and the associated DA led to the closures of fisheries, such as Dungeness crab, rock crab, razor clam, etc. Local economy suffered serious losses from the closures of fisheries, with a USD\$97.5 million decrease in revenue for the commercial Dungeness crab fishery alone occurred in 2015 compared to 2014 (Trainer et al., 2020). The frequent occurrence of red tides induced by MHWs indicates that MHWs could reduce biodiversity of microalgae and even higher trophic levels via food chain.

\section{Reasons for Algal Blooms Related to Marine Heatwaves}

Warming and MHWs could enhance stratification of the upper ocean and hence hinder the nutrient transport from deeper to surface waters, leading to reduced nutrient availability in the upper waters (Trainer et al., 2020). Therefore, phytoplankton species with unique nutrient acquisition strategies are able to successfully outcompete under these nutrient limiting conditions and develop to blooms. These strategies include enhanced "surge" macronutrient uptake rates, unique trace metal uptake capabilities, mixotrophy, and swimming to areas where nutrient levels are higher (Smayda, 2010). In addition, bloom-forming algae can produce and excrete toxins that can kill not only their grazers but also other algal species (Granéli et al., 2008). Killing the nutrient-competing phytoplankton species enables harmful species to freely utilize limiting nutrients. The decreased grazing pressure and competitors facilitate the harmful algae to form a dominant position. Therefore, altered intensity of stratification or ocean mixing and the sequent changes in nutrient availability 
could be a main link between marine heatwaves and microalgal blooms/composition.

Meanwhile, longstanding and large-scale algal blooms must be supported by enough nutrient availability. For instance, the largest harmful algal bloom ever recorded that extended from southern California to southeast Alaska during the 2014-2016 marine heatwave, is clearly supported by the spring upwelling (Trainer et al., 2020). Furthermore, the analyses of SST, chlorophyll $a$ and nitrate based on satellite observations and in situ climatology show that algal blooms associated with MHWs are weaker in nutrient-poor waters and stronger in nutrient-rich waters (Hayashida et al., 2020). Given strengthened stratification and decreased nutrient availability in upper waters in future oceans, enhanced occurrence of weaker blooms caused by marine heatwaves could be expected in coming decades.

\section{Recovery and Acclimation of Algae}

Whether algae would recover after MHWs firstly depends on the intensity of MHWs they are exposed to. Both three and six degrees centigrade elevation of MHWs reduced gross photosynthetic rate and light utilization efficiency of the sugar kelp Saccharina latissimi (Nepper-Davidsen et al., 2019). During the recovery period, thalli experiencing the lighter MHWs recovered to the same levels as control but thalli experiencing the heavier MHWs still had suppressed performance compared to the control (Nepper-Davidsen et al., 2019). Similarly, the macrophyte community structure at shallower sites did not show any recovery sign after the 2011 Western Australian MHWs while the deep populations generally persisted due to the lighter MHWs it experienced (GiraldoOspina et al., 2020). Recovery capacity is also species-dependent. Devalerea/Palmaria, encrusting coralline algae, and Halosaccion suffer from continuous decrease during/after the MHWs in the Northern Gulf of Alaska, while Cladophora/Chaetomorpha, Fucus, and Odonthalia/Neorhodomela decreased during MHWs but appeared to be recovering after MHWs (Weitzman et al., 2021). In most cases, large-scale reversal from turfs to kelp forests has not been found after MHWs (FilbeeDexter and Wernberg, 2018). A possible reason is that humandriven environmental changes such as ocean warming or coastal eutrophication are favoring the growth and thriving of turfs over kelps. Turfs can prevent the recovery of kelps through plundering light and space and by reducing the availability of kelp propagules. In addition, increased grazing pressure on kelps due to tropicalization facilitated the expansion of turfs while preventing the kelps from recovering (Bennett et al., 2015).

Some marine organisms demonstrate ecological memory or acclimation to $\mathrm{MHWs}$. In 2016, an exposure to $8-9^{\circ} \mathrm{C}$ MHWs led to over $90 \%$ probability of severe corals (microalgal symbionts) bleaching on the Great Barrier Reef while the same intensity of MHWs in 2017 induced a 50\% probability of severe bleaching (Hughes et al., 2019). In parallel, adult brown seaweed Fucus vesiculosus experienced three MHWs had higher growth rate $(0.57 \pm 0.36 \mathrm{~mm} /$ day $)$ than that $(0.45 \pm 0.40 \mathrm{~mm} /$ day $)$ experienced one MHW, although both of them were lower than the control $(0.67 \pm 0.08 \mathrm{~mm} /$ day $)$ that did not experience MHWs, suggesting the acclimation to MHWs (Saha et al., 2020).

\section{CARBON SEQUESTRATION BY ALGAE UNDER MARINE HEATWAVES}

Carbon sequestration by algae could be defined as the process that $\mathrm{CO}_{2}$ is captured and fixed by algae and then stored in oceans for long times (usually more than 100 years) in the form of sediments or refractory dissolved organic carbon. Unfortunately, very few documents have been found on how many amounts of $\mathrm{CO}_{2}$ are sequestered by algae in the context of MHWs (Figure 1). In this study, we mainly reviewed the impacts of MHWs on carbon fixation or biomass in algae instead because the sequestered carbon is closely related to fixed carbon. For instance, sequestered carbon by wild macroalgae and phytoplankton accounts for $11.4 \%$ and $1.2-2.4 \%$ of their net primary production, respectively (Legendre et al., 2015; Krause-Jensen and Duarte, 2016).

The decreased growth and high mortality of canopy-forming macroalgae caused by MHWs would lead to the decrease of carbon burial and sequestration by these macroalgae. However, the lost carbon may be offset by increased biomass of invasive macroalgae or turfs. It has been found that the amount of fixed carbon by a fast-growing non-indigenous kelp Undaria pinnatifida in a 6-month period is close to that by a native Cystophora torulosa in a year (Tait et al., 2015), indicating that higher daily rates of carbon fixation offset the limited growing season of $U$. pinnatifida. In parallel, the presence of the invasive brown alga Sargassum horneri did not affect community production although it contributed to ephemeral increases in gross community production (Sullaway and Edwards, 2020), which may be due to the increased community respiration. The constant erosion of tissue at the distal margins and higher biomass variation for annual lifecycle make $S$. horneri have inherently higher turnover rates compared to perennial canopyforming kelp (Sullaway and Edwards, 2020), which may reduce long-term carbon sequestration of a community dominated by ephemeral seaweeds.

In terms of microalgae, all El Niño events in 1982-1983, 1997-1998, and 2015-2016 led to low phytoplankton biomass and primary productivity in the northeast Pacific. The decreased primary productivity could be attributed to weak upwelling and/or a deep pycnocline/nutricline caused by warm events, each of which reduced nutrient supply to the surface mixed layer (Jacox et al., 2016). On the other hand, Montie et al. (2020) examined the effects of 19 extreme summer MHWs on chlorophyll $a$ (chl a) concentration in the Southern Ocean (SO) and found that extreme summer MHWs increased surface chl $a$ by $\sim 80 \%$ compared to control sites, with the strongest effects in the coldest regions. The MHWs in the New Zealand region imposed different impacts on primary production and generally reduced surface phytoplankton biomass in the north of the Subtropical Front but increased biomass in south of the Subtropical Front (Chiswell and Sutton, 2020). The differential impacts might be related to the local temperatures. The temperatures in north of the Subtropical Front are much 
higher than those in south of the Subtropical Front. Therefore, temperature rise may be beneficial to phytoplankton at lower temperatures but be beyond the thermal limit for phytoplankton at higher temperatures.

Sen Gupta et al. (2020) systematically identified commonalities in the local processes and atmospheric conditions that initiate and terminate extreme MHWs during the period from 1982 to 2017 and analyzed regionally dependent responses of surface chlorophyll- $a$ concentration to these events. The results showed that decreased chlorophyll- $a$ concentrations occurred during the majority of extreme MHWs. On the other hand, increased productivity was also found during some MHWs. The effects of MHWs depended largely on latitude. The general pattern is that negative effects occurred at low and mid-latitudes while positive effects came up at high latitudes. The possible reason is that intensified stratification suppresses the supply of nutrients from deeper to the upper oceans, which is fatal for phytoplankton in oligotrophic tropical and subtropical waters where nutrient levels are extremely low. By contrast, phytoplankton at high latitudes are more often light rather than nutrients limited (Falkowski, 1994); stratification can reduce mixing and thus expose algae to more solar radiation, increasing light availability and facilitating photosynthesis and growth of phytoplankton.

\section{MARINE HEATWAVES COMBINED WITH OCEAN ACIDIFICATION AND WARMING}

\section{Algal Structure}

Apart from microalgal blooms, macroalgal blooms have also gained increased concerns. It has been shown that macroalgal bloom is in a rising trend, which may be related to enhanced eutrophication (Smetacek and Zingone, 2013). Furthermore, Xu et al. (2017) found that ocean acidification could enhance carbon and nitrogen assimilation rates of a golden tide alga and thereby growth rates, indicating that golden tides may be stimulated by future ocean acidification. Gao et al. (2017a) investigated the effects of ocean acidification, warming and eutrophication on a green tide alga and found the combination of these three factors increased settlement, germination of gametes and growth of juvenile and adult thalli of Ulva rigida, stimulated reproduction of adult thalli and thus shortened its life cycle. Accordingly, green tides are predicted to increase in future ocean conditions (warming and acidification), suggesting the increase of floating macroalgae. Furthermore, Britton et al. (2020) investigated the effects of MHWs on the physiological performance of the brown seaweed Phyllospora comosa in the current and future (warming and acidification) ocean conditions. MHWs decreased its growth rates in both current and future conditions. Warming and acidification also reduced its growth rates. Therefore, the combination of MHWs, warming and acidification resulted in the lowest growth rate of $P$. comosa. $P$. comosa down-regulated carbon dioxide concentrating mechanism in the future conditions and the saved energy arising from this down-regulation was invested in the adjustment of fatty acid composition. Although it seems a response to a changed environment, it did not alleviate the negative effects of marine heatwaves and ocean warming on the growth of P. comosa. In parallel, Falkenberg et al. (2013) found that ocean acidification increased the growth of turf-forming algae but did not affect kelp's growth. The differential response may be related to their carbon acquisition mechanisms. Some turf-forming algae acquire $\mathrm{CO}_{2}$ through passive diffusion, whilst complex canopyforming species, like kelp, possess efficient CCMs (Hepburn et al., 2011; Falkenberg et al., 2013). Therefore current $\mathrm{CO}_{2}$ level should be more limited for turfs than kelps. From this point of view, ocean acidification may enhance the competition of turfs against kelps and exacerbate the trend of kelp loss caused by MHWs. In addition, ocean warming trends to increase grazing pressure of kelps but reduce it for turfs (Mertens et al., 2015), which accelerates the shift from kelps to turfs.

Increased $\mathrm{CO}_{2}$-driven climate change has evident impacts on species composition and size structure of phytoplankton (Falkowski and Oliver, 2007; Winder and Sommer, 2012). Hinder et al. (2012) found the abundance of dinoflagellates decreased while diatoms increased in the northeast Atlantic and North Sea across a 50-year (1960-2009) time series. This shift was attributed to the combined effect of ocean warming and increasingly windy conditions in summer. On the other hand, it has been predicted that cyanobacteria would gain more competitive advantages against diatoms in future open oceans (Falkowski and Oliver, 2007; Finkel et al., 2010). The contrasting findings above are probably due to the change of turbulent mixing. In coastal oceans, the increase of thermal contrast between the continents and the coastal oceans due to global warming may strengthen wind-driven upwelling, which would enhance the competitive advantage of diatoms (Falkowski and Oliver, 2007). Diatoms have a storage vacuole for nutrients which makes them acclimate well to the environment with pulsed nutrient supply (Tozzi et al., 2004). In addition, diatoms have distinctive photoprotection mechanisms to cope with rapid fluctuations of underwater light environment (Gao et al., 2018c,d). The features above support the dominance of diatoms in intensified mixing environments. In contrast to coastal oceans, mixing would be weakened and stratification would be strengthened in future open oceans, leading to decreased nutrient supply from deeper waters. Smaller phytoplankton such as cyanobacteria would be favored in a nutrient limited environment because they have larger ratios of cell volume to surface area and higher nutrient uptake efficiency. The combined effects of MHWs and ocean warming/acidification on phytoplankton community structure have not been documented although the combination of warming and heatwaves catalyze blooms of buoyant cyanobacteria in lakes (Bartosiewicz et al., 2019; Filiz et al., 2020). One important reason that cyanobacteria can outcompete other phytoplankton taxa is that cyanobacteria have higher specific growth rates at higher temperatures compared to other taxa (Jöhnk et al., 2008). To summarize, we propose that in future scenarios, diatoms would have competitive advantages in coastal oceans but their territory would be nibbled by smaller cyanobacteria such as Prochlorococcus and Synechococcus in open oceans (Figure 2). More studies are needed to test this hypothesis. 


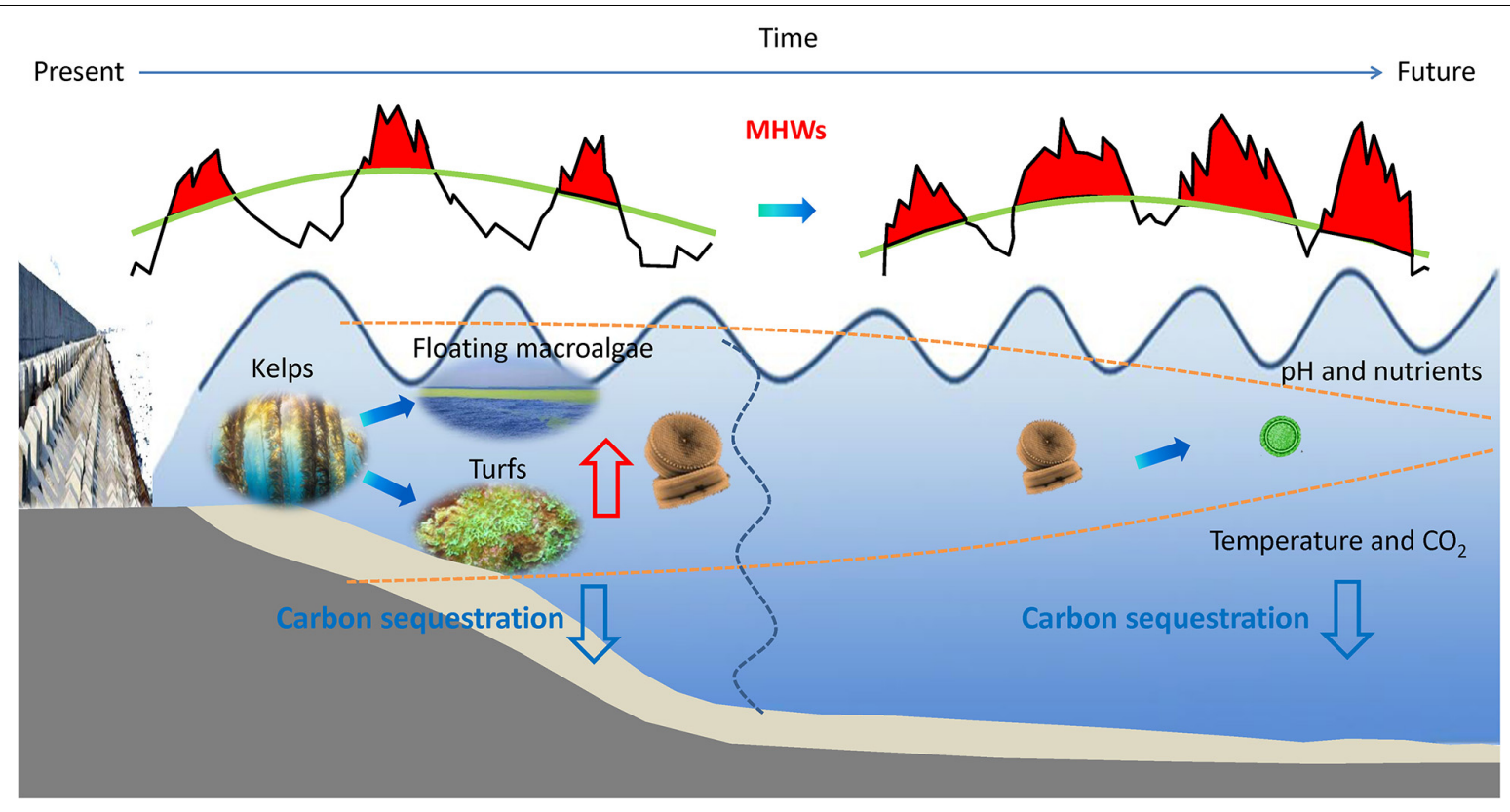

FIGURE 2 | Illustration of the hypothesis on the alteration of algal structure and carbon sequestration in future oceans. MHWs combined with ocean warming and acidification would facilitate the survival of turfs, floating macroalgae and diatoms in coastal oceans, and smaller cyanobacteria in open oceans; carbon sequestration by marine primary producers is predicted to decrease due mainly to the decreased primary production and carbon sink rates. Red arrow represents a rising trend and blue arrows represent a decreasing trend.

Studies mentioned above investigated the impacts of climate change variables on macroalgae or microalgae separately. However, in the natural environments, they co-occur in coastal oceans and the increase of floating macroalgae expands the overlap between them. In the same ecological niche, macroalgae and microalgae inevitably compete for resources, like nutrients, light and space. Sun et al. (2018) found that there was a negative correlation between the occurrence of macroalga Ulva prolifera and chlorophyll-a concentration in the Southern Yellow Sea, China. Who will be the winner in future oceans? In contrast to the studies based on individual investigation on microalgae or macroalgae, Gao et al. (2019a) co-cultured red tide forming alga Skeletonema costatum and green tide forming alga Ulva linza under current and future ocean conditions. Compared to U. linza, S. costatum had more advantages in future warming and acidification conditions, which may suppress the development of green tides caused by Ulva species. The decreased trend of green tides and increased occurrence of red tides in Chinese seas in recent years also support this finding (China Marine Disaster Bulletin, 2000-2020). Microalgae, particularly some bloom-forming species, have higher thermal tolerance compared to macroalgae (Jöhnk et al., 2008). Therefore, we predict that microalgae may win in the competition with macroalgae in future oceans with frequent MHWs.

\section{Carbon Sequestration}

According to Britton et al. (2020), the combination of MHWs, warming and acidification significantly decreased growth of the brown seaweed Phyllospora comosa. In addition, warming or acidification could enhance the respiration rate of seaweeds, which may result in decreased net carbon fixation (Gao et al., 2019b; Liu et al., 2020). The decreased growth and carbon fixation would lead to the decline of carbon that is finally sequestrated considering that there is a relatively stable proportion of carbon sequestration to carbon fixation (KrauseJensen and Duarte, 2016). In parallel, the kelp loss in Australian over the past decades has led to $0.45 \mathrm{Tg} \mathrm{C}$ of lost standing stock and $0.06 \mathrm{Tg} \mathrm{C}$ of lost sequestration annually due to MHWs, warming and climate-driven changes including sea urchin overgrazing and the influx of tropical herbivores with warmer waters (Filbee-Dexter and Wernberg, 2020). Therefore, decreased $\mathrm{CO}_{2}$ sequestration by seaweeds could be expected in future ocean conditions although more studies need to be conducted. In addition, increased $\mathrm{CO}_{2}$ did not affect carbon content of turfs but enhanced nitrogen content, leading to decreased C:N ratios. In contrast, neither $\mathrm{C}$ nor $\mathrm{N}$ content of kelps was affected by increased $\mathrm{CO}_{2}$ and thereby the $\mathrm{C}: \mathrm{N}$ ratio kept consistent (Falkenberg et al., 2013). Given the shift from kelps to turfs, these findings indicate that ocean acidification may reduce carbon fixation and hence sequestration of seaweed community by affecting C:N ratio even if seaweed biomass does not change.

In terms of microalgae, some studies have shown that ocean acidification or warming could stimulate primary production (Schippers et al., 2004; Gao et al., 2017b), but the combination of ocean warming and acidification or the interactions with other environmental drivers could reduce ocean primary productivity (Gao et al., 2012, 2017b). In fact, the primary productivity of global phytoplankton shows a decreasing trend in recent decades (Gregg and Rousseaux, 2019; Kulk et al., 2020). The trend is very 


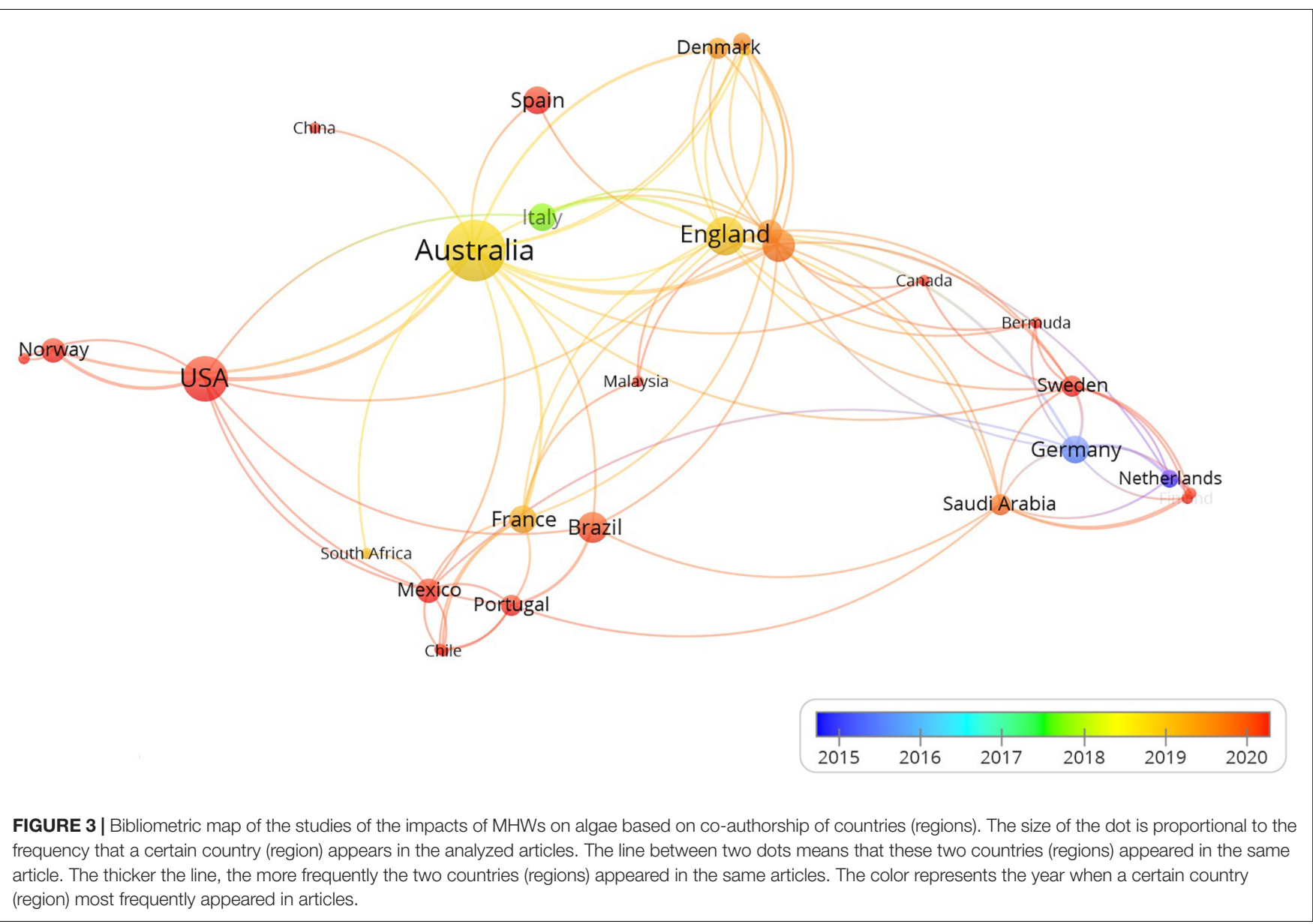

likely to be driven by the reduced nutrient availability caused by ocean warming and consequently enhanced stratification. The reduced primary productivity that represents less carbon is fixed would result in a decline of carbon sequestration. Furthermore, ocean warming could also stimulate the remineralization of fixed carbon by heterotrophic microorganisms and thus lead to a further decline of carbon sequestration (Cavan et al., 2019). The combined effects of ocean warming and acidification with MHWs on carbon sequestration by microalgae have not been documented. However, carbon sequestration by phytoplankton could be predicted to decrease in future warmer and $\mathrm{CO}_{2}$-enriched oceans due to the community shift from larger cells to smaller cells from diatoms to cyanobacteria because larger cells sink fasters than smaller cells and diatoms sink faster than cyanobacteria (Falkowski and Oliver, 2007; Winder and Sommer, 2012).

\section{CONCLUSION AND FUTURE RESEARCH NEEDS}

\section{Conclusion}

As $\mathrm{CO}_{2}$ is emitted continuously, MHWs are projected to be exacerbated by rising global temperatures. However, how (micro) algae respond to MHWs is fragmentary, particularly in terms of carbon sequestration and in conjunction with ocean warming and acidification. In this study, through reviewing the published data, we find that MHWs are driving the regime shift from canopy-forming to turf-forming and floating macroalgae and inducing microalgal blooms. It seems that MHWs would reduce carbon sequestration of macroalgae due to the quick turnover rate of carbon in turf-forming and floating macroalgae. Therefore, this structure shift would reduce effective services that canopy-forming can provide. Meanwhile, MHWs combined with ocean warming and acidification trends to facilitate the growth of smaller phytoplankton and thus reduce carbon sink and sequestration by phytoplankton (Figure 2).

\section{Research Needs}

(1) Impacts on seaweed cultivation

With the increasing knowledge on seaweed values in food, chemical industry, and medicine, worldwide seaweed cultivation is expanding. In 2005, the world production of seaweeds from cultivation increased from 13.5 million tons in 2005 to 32.4 million tons in 2018 (Ferdouse et al., 2018; FAO, 2020). However, most studies till now focus on natural kelp forests and little is known regarding the effects of MHWs on farmed seaweeds. In recent years, farmed seaweeds often suffer from sudden decay 
and death, which may be related to increased MHW events. Since farmed seaweeds play an important role in remitting coastal eutrophication in addition to supply marine vegetables (Xiao et al., 2017; Gao et al., 2018b), future studies should pay more attention to the potential effects of MHWs on production and biochemical composition of farmed seaweeds.

\section{(2) Combined effects of MHWs and other factors}

Algae at different locations respond differentially to MHWs. In addition to the species differences, the regulation by other factors, including background temperature, nutrient and light levels, desiccation stress and grazing pressure, may be the main driver. Therefore, more MHWs-simulating studies should be conducted to disentangle impacts caused by the extreme temperature increases of MHWs itself from co-occurring other factors, and to understand the combined effects of MHWs and other potential stressors. In addition, as climate change continues, our understanding on how MHWs affect algae in future warming and $\mathrm{CO}_{2}$-enriched oceans needs to be advanced.

\section{(3) Interaction between macroalgae and microalgae}

Most studies investigated the impacts of MHWs on microalgae or macroalgae individually. However, microalgae and macroalgae overlap in coastal waters and compete for resources. The attachment of microalgae on the surface of macroalgae could negatively affect the growth of macroalgae particularly for the juvenile, mainly through reducing light and nutrient availability. Meanwhile, macroalgae could inhibit the growth of microalgae around them via excreting allelopathic chemicals (Tang and Gobler, 2011; Gao et al., 2019a). Therefore, microalgal blooms are significantly inhibited in the areas where macroalgae are intensively cultivated. On the other hand, sporadic microalgal blooms are found in macroalgae farms in recent years. Given differential response of microalgae and macroalgae to MHWs, the current balance between microalgae and macroalgae may be broken up by MHWs. Therefore, given the significance of macroalgae cultivation and harmful algal bloom, it is urgent to investigate whether the interaction of microalgae and macroalgae will be altered by MHWs.

(4) Carbon path of algae under MHWs

Algae take up $\mathrm{CO}_{2}$ in seawater or air and convert it into organic carbon. Apart from meeting the demand for their own growth and metabolism, a considerable proportion of fixed organic carbon is excreted to the environment as the form of dissolved organic carbon (DOC). Labile DOC can be consumed and utilized by bacteria and the remaining part is resistant to external factors, termed as refractory DOC. Refractory DOC can be stored in the oceans for thousands of years and play an essential role in carbon sink of oceans (Santos et al., 2021). Previous studies refer to photosynthetic performance of algae but it is unknown how MHWs would affect the excretion of DOC from algae and the transformation from labile DOC to refractory DOC (Figure 1). To understand the impacts of MHWs on carbon sequestration of oceans, studies on this field must be carried out.

\section{(5) MHWs prediction and macroalgae monitoring}

Due to the compelling evidence for devastating impacts of MHWs on marine ecosystems, precise prediction of MHWs is urgently needed, particularly considering that global warming would enhance the occurrences and intensities of MHWs. In spite of increasing understanding on processes and mechanisms of MHWs, MHWs-prediction systems are in their infancy and MHWs forecast is not set in most countries. To guide marine conservation, fisheries management and aquaculture activities and reduce ecological and economic loss, MHWs predictability must be improved. In addition, to link the variation of macroalgal forests with MHWs, it is compulsory to know the dynamic distribution of benthic macroalgae. Although there are some programs monitoring macroalgal forests, coverage is very patchy (Duffy et al., 2019). Many regions are difficult to survey because of the cold, turbid, deep, and/or wave-exposed environments that hinder accessibility. Remote surveying with satellites seems to be promising but the spatio-temporal resolution needs to be improved considering that macroalgae usually inhabit in narrow coastal areas and the distribution of many macroalgal forests are highly dynamic across time and space.

(6) Global research and cooperation

Current studies on MHWs have mainly been carried out in western countries, particularly developed countries, such as the United States, Australia and the United Kingdom; while little information from Asian and African countries is available (Figure 3). MHWs occur in global seas and oceans. The research disequilibrium hinders us from understanding the global impacts of MHWs. Asia and Africa are the main ground of seaweed cultivation. Therefore, there is urgent need to conduct or strengthen the MHWs research in developing countries. International cooperation is strongly encouraged because it facilitates the success of research in countries (regions) where MHWs are poorly understood and the formation of uniform methodologies.

\section{AUTHOR CONTRIBUTIONS}

GG contributed to the theoretical designs, data analysis, and writing of the manuscript. XZ, MJ, and LG contributed to writing of the manuscript. All authors contributed to the article and approved the submitted version.

\section{FUNDING}

This work was supported by the National Natural Science Foundation of China (42076154), the National Key Research and Development Program of China (2018YFD0900703), the MEL Internal Research Program (MELRI2004), and the Fundamental Research Funds for the Central Universities (20720200111). 


\section{REFERENCES}

Airoldi, L. (1998). Roles of disturbance, sediment stress, and substratum retention on spatial dominance in algal turf. Ecology 79, 2759-2770. doi: 10.1890/00129658(1998)079[2759:rodssa]2.0.co;2

Andersen, S. G., Steen, H., Christie, H., Fredriksen, S., and Moy, F. E. (2011). Seasonal patterns of sporophyte growth, fertility, fouling, and mortality of Saccharina latissima in Skagerrak, Norway: implications for forest recovery. J. Mar. Biol. 2011:690375.

Atkinson, J., King, N. G., Wilmes, S. B., and Moore, P. J. (2020). Summer and winter marine heatwaves favor an invasive over native seaweeds. J. Phycol. 56, 1591-1600. doi: 10.1111/jpy.13051

Bartosiewicz, M., Przytulska, A., Deshpande, B. N., Antoniades, D., Cortes, A., MacIntyre, S., et al. (2019). Effects of climate change and episodic heat events on cyanobacteria in a eutrophic polymictic lake. Sci. Total Environ. 693:133414. doi: 10.1016/j.scitotenv.2019.07.220

Bennett, S., Wernberg, T., Harvey, E. S., Santana-Garcon, J., and Saunders, B. J. (2015). Tropical herbivores provide resilience to a climate-mediated phase shift on temperate reefs. Ecol. Lett. 18, 714-723. doi: 10.1111/ele.12450

Benthuysen, J. A., Oliver, E. C., Chen, K., and Wernberg, T. (2020). Advances in understanding marine heatwaves and their impacts. Front. Mar. Sci. 7:147. doi: 10.3389/fmars.2020.00147

Britton, D., Schmid, M., Noisette, F., Havenhand, J. N., Paine, E. R., McGraw, C. M., et al. (2020). Adjustments in fatty acid composition is a mechanism that can explain resilience to marine heatwaves and future ocean conditions in the habitat-forming seaweed Phyllospora comosa (Labillardière) C. Agardh. Global Change Biol. 26, 3512-3524. doi: 10.1111/gcb.15052

Cavan, E. L., Henson, S. A., and Boyd, P. W. (2019). The sensitivity of subsurface microbes to ocean warming accentuates future declines in particulate carbon export. Front. Ecol. Evol. 6:230. doi: 10.3389/fevo.2018.00230

China Marine Disaster Bulletin (2000-2020). Ministry of Natural Resources of the Peopl's Republic of China, Beijing. Beijing: China Marine Disaster Bulletin.

Chiswell, S. M., and Sutton, P. J. H. (2020). Relationships between long-term ocean warming, marine heat waves and primary production in the New Zealand region. New Zealand J. Mar. Freshwater Res. 54, 614-635. doi: 10.1080/ 00288330.2020 .1713181

Cochlan, W. P., Herndon, J., and Kudela, R. M. (2008). Inorganic and organic nitrogen uptake by the toxigenic diatom Pseudo-nitzschia australis (Bacillariophyceae). Harmful Algae 8, 111-118. doi: 10.1016/j.hal.2008.08.008

Connell, S. D., and Russell, B. D. (2010). The direct effects of increasing CO2 and temperature on non-calcifying organisms: increasing the potential for phase shifts in kelp forests. Proc. R. Soc. London B. 277, 1409-1415. doi: 10.1098/ rspb.2009.2069

Connell, S. D., Russell, B. D., Turner, D. J., Shepherd, S. A., Kildea, T., Miller, D., et al. (2008). Recovering a lost baseline: missing kelp forests from a metropolitan coast. Mar. Ecol. Prog. Ser. 360, 63-72. doi: 10.3354/meps07526

Dee, S., Cuttler, M., Cartwright, P., McIlwain, J., and Browne, N. (2021). Encrusters maintain stable carbonate production despite temperature anomalies among two inshore island reefs of the Pilbara, Western Australia. Mar. Environ. Res. 2021:105386. doi: 10.1016/j.marenvres.2021.105386

Duffy, J. E., Benedetti-Cecchi, L., Trinanes, J., Muller-Karger, F. E., Ambo-Rappe, R., Boström, C., et al. (2019). Toward a coordinated global observing system for seagrasses and marine macroalgae. Front. Mar. Sci. 6:317. doi: 10.3389/fmars. 2019.00317

Falkenberg, L. J., Russell, B. D., and Connell, S. D. (2013). Contrasting resource limitations of marine primary producers: implications for competitive interactions under enriched CO 2 and nutrient regimes. Oecologia 172, 575-583. doi: $10.1007 / \mathrm{s} 00442-012-2507-5$

Falkowski, P. G. (1994). The role of phytoplankton photosynthesis in global biogeochemical cycles. Photosynthesis Res. 39, 23-258.

Falkowski, P. G., Barber, R. T., and Smetacek, V. (1998). Biogeochemical controls and feedbacks on ocean primary production. Science 281, 200-206. doi: 10 . $1126 /$ science. 281.5374 .200

Falkowski, P. G., and Oliver, M. J. (2007). Mix and match: how climate selects phytoplankton. Nat. Rev. Microbiol. 5, 813-819. doi: 10.1038/nrmicro1751

FAO (2020). FAO Yearbook. Fishery and Aquaculture Statistics 2018/FAO Annuaire. Statistiques des Pêches et de L'aquaculture 2018/FAO Anuario. Estadísticas de Pesca y Acuicultura 2018. FAO: Rome, doi: 10.4060/cb1213t
Ferdouse, F., Holdt, S. L., Smith, R., Murúa, P., and Yang, Z. (2018). The global status of seaweed production, trade and utilization. FAO Globefish Res. Prog. 124:120.

Fernandez, C. (2011). The retreat of large brown seaweeds on the north coast of Spain: the case of Saccorhiza polyschides. Eur. J. Phycol. 46, 352-360. doi: 10.1080/09670262.2011.617840

Fernández, P. A., Gaitán-Espitia, J. D., Leal, P. P., Schmid, M., Revill, A. T., and Hurd, C. L. (2020). Nitrogen sufficiency enhances thermal tolerance in habitat-forming kelp: implications for acclimation under thermal stress. Sci. Rep. 10:3186.

Filbee-Dexter, K., Feehan, C. J., and Scheibling, R. E. (2016). Large-scale degradation of a kelp ecosystem in an ocean warming hotspot. Mar. Ecol. Prog. Ser. 543, 141-152. doi: 10.3354/meps11554

Filbee-Dexter, K., and Scheibling, R. E. (2012). Hurricane-mediated defoliation of kelp beds and pulsed delivery of kelp detritus to offshore sedimentary habitats. Mar. Ecol. Prog Ser. 455, 51-64. doi: 10.3354/meps09667

Filbee-Dexter, K., and Wernberg, T. (2018). Rise of turfs: a new battlefront for globally declining kelp forests. Bioscience 68, 64-76. doi: 10.1093/biosci/bix147

Filbee-Dexter, K., and Wernberg, T. (2020). Substantial blue carbon in overlooked Australian kelp forests. Sci. Rep. 10:12341.

Filiz, N., Işkıın, U., Beklioð̋lu, M., Öðlü, B., Cao, Y., Davidson, T. A., et al. (2020). Phytoplankton community response to nutrients, temperatures, and a heat wave in shallow lakes: an experimental approach. Water 12:3394. doi: $10.3390 /$ w12123394

Finkel, Z. V., Beardall, J., Flynn, K. J., Quigg, A., Rees, T. A. V., and Raven, J. A. (2010). Phytoplankton in a changing world: cell size and elemental stoichiometry. J. Plankton Res. 32, 119-137. doi: 10.1093/plankt/fbp098

Gao, G., Burgess, J. G., Wu, M., Wang, S., and Gao, K. (2020). Using macroalgae as biofuel: current opportunities and challenges. Botanica Marina 63, 355-370. doi: 10.1515/bot-2019-0065

Gao, G., Clare, A. S., Chatzidimitriou, E., Rose, C., and Caldwell, G. (2018a). Effects of ocean warming and acidification, combined with nutrient enrichment, on chemical composition and functional properties of Ulva rigida. Food Chem. 258, 71-78. doi: 10.1016/j.foodchem.2018.03.040

Gao, G., Clare, A. S., Rose, C., and Caldwell, G. S. (2018b). Ulva rigida in the future ocean: potential for carbon capture, bioremediation and biomethane production. Global Change Biol. Bioenergy 10, 39-51. doi: 10.1111/gcbb.12465

Gao, G., Shi, Q., Xu, Z., Xu, J., Campbell, D. A., and Wu, H. (2018c). Global warming interacts with ocean acidification to alter PSII function and protection in the diatom Thalassiosira weissflogii. Environ. Exp. Bot. 147, 95-103. doi: 10.1016/j.envexpbot.2017.11.014

Gao, G., Xu, Z., Shi, Q., and Wu, H. (2018d). Increased CO2 exacerbates the stress of ultraviolet radiation on photosystem II function in the diatom Thalassiosira weissflogii. Environ. Exp. Bot. 156, 96-105. doi: 10.1016/j.envexpbot.2018.08. 031

Gao, G., Clare, A. S., Rose, C., and Caldwell, G. S. (2017a). Eutrophication and warming-driven green tides (Ulva rigida) are predicted to increase under future climate change scenarios. Mar. Pollut. Bull. 114, 439-447. doi: 10.1016/j. marpolbul.2016.10.003

Gao, G., Jin, P., Liu, N. N., Li, F. T., Tong, S. Y., Hutchins, D. A., et al. (2017b). The acclimation process of phytoplankton biomass, carbon fixation and respiration to the combined effects of elevated temperature and $\mathrm{pCO} 2$ in the northern South China Sea. Mar. Pollut. Bull. 118, 213-220. doi: 10.1016/j.marpolbul. 2017.02.063

Gao, G., Fu, Q. Q., Beardall, J., Wu, M., and Xu, J. T. (2019a). Combination of ocean acidification and warming enhances the competitive advantage of Skeletonema costatum over a green tide alga, Ulva linza. Harmful Algae 85:101698. doi: 10.1016/j.hal.2019.101698

Gao, G., Gao, Q., Bao, M. L., Xu, J. T., and Li, X. S. (2019b). Nitrogen availability modulates the effects of ocean acidification on biomass yield and food quality of a marine crop Pyropia yezoensis. Food Chem. 271, 623-629. doi: 10.1016/j. foodchem.2018.07.090

Gao, G., Zhong, Z. H., Zhou, X. H., and Xu, J. T. (2016). Changes in morphological plasticity of Ulva prolifera under different environmental conditions: a laboratory experiment. Harmful Algae 59, 51-58. doi: 10.1016/j.hal.2016.09.004

Gao, K., Xu, J., Gao, G., Li, Y., Hutchins, D. A., Huang, B., et al. (2012). Rising CO2 and increased light exposure synergistically reduce marine primary productivity. Nat. Climate Change 2, 519-523. doi: 10.1038/nclimate1507 
Giraldo-Ospina, A., Kendrick, G. A., and Hovey, R. K. (2020). Depth moderates loss of marine foundation species after an extreme marine heatwave: could deep temperate reefs act as a refuge? Proc. R. Soc. B-Biol. Sci. 287:20200709. doi: $10.1098 / \mathrm{rspb} .2020 .0709$

Gorman, D., Russell, B. D., and Connell, S. D. (2009). Land-to-sea connectivity: linking human-derived terrestrial subsidies to subtidal habitat change on open rocky coasts. Ecol. Appl. 19, 1114-1126. doi: 10.1890/08-0831.1

Graham, M. H., Vasquez, J. A., and Buschmann, A. H. (2007). Global ecology of the giant kelp Macrocystis: from ecotypes to ecosystems. Oceanography Mar. Biol. 45, 39-88. doi: 10.1201/9781420050943.ch2

Granéli, E., Salomon, P. S., and Fistarol, G. O. (2008). “The role of allelopathy for harmful algae bloom formation," in Algal Toxins: Nature, Occurrence, Effect and Detection evangelista, eds V. Barsanti, A. M. Frassanito, V. Passarelli, and P. Gualtieri (Dordrecht: Springer), 159-178.

Gregg, W. W., and Rousseaux, C. S. (2019). Global ocean primary production trends in the modern ocean color satellite record (1998-2015). Environ. Res. Lett. 14:124011. doi: 10.1088/1748-9326/ab4667

Hasle, G. R., and Syvertsen, E. E. (1997). "Marine diatoms," in Identifying Marine Phytoplankton, ed. C. R. Tomas (San Diego, CA: Academic Press), 5-385. doi: 10.1016/b978-012693015-3/50005-x

Hayashida, H., Matear, R. J., and Strutton, P. G. (2020). Background nutrient concentration determines phytoplankton bloom response to marine heatwaves. Global Change Biol. 26, 4800-4811. doi: 10.1111/gcb.15255

Hein, M., Pedersen, M. F., and Sandjensen, K. (1995). Size-dependent nitrogen uptake in micro - and macroalgae. Mar. Ecol. Prog. Ser. 118, 247-253. doi: 10.3354/meps 118247

Hepburn, C. D., Pritchard, D. W., Cornwall, C. E., McLeod, R. J., Beardall, J., Raven, J. A., et al. (2011). Diversity of carbon use strategies in a kelp forest community: implications for a high CO2 ocean. Global Change Biol. 17, 2488-2497. doi: 10.1111/j.1365-2486.2011.02411.x

Hinder, S. L., Hays, G. C., Edwards, M., Roberts, E. C., Walne, A. W., and Gravenor, M. B. (2012). Changes in marine dinoflagellate and diatom abundance under climate change. Nat. Climate Change 2, 271-275. doi: 10.1038/nclimate1388

Hobday, A. J., Alexander, L. V., Perkins, S. E., Smale, D. A., Straub, S. C., Oliver, E. C. J., et al. (2016). A hierarchical approach to defining marine heatwaves. Prog. Oceanography 141, 227-238. doi: 10.1016/j.pocean.2015.12.014

Hughes, T. P., Kerry, J. T., Connolly, S. R., Baird, A. H., Eakin, C. M., Heron, S. F., et al. (2019). Ecological memory modifies the cumulative impact of recurrent climate extremes. Nat. Climate Change 9, 40-43. doi: 10.1038/s41558-0180351-2

IPCC (2013). "Summary for policymakers: climate change 2013 - the physical science basis," in Working Group 1 Contribution to the IPCC Fifth Assessment Report, eds T. F. S. T. G. Stocker, D. Qin, G.-K. Plattner, M. Tignor, S. K. Allen, and J. Boschung (Cambridge: Cambridge University Press).

Jacox, M. G., Hazen, E. L., Zaba, K. D., Rudnick, D. L., Edwards, C. A., Moore, A. M., et al. (2016). Impacts of the 2015-2016 El Niño on the california current system: early assessment and comparison to past events. Geophys. Res. Lett. 43, 7072-7080.

Jöhnk, K. D., Huisman, J. E. F., Sharples, J., Sommeijer, B. E. N., Visser, P. M., and Stroom, J. M. (2008). Summer heatwaves promote blooms of harmful cyanobacteria. Global Change Biol. 14, 495-512. doi: 10.1111/j.1365-2486.2007. 01510.x

Krause-Jensen, D., and Duarte, C. M. (2016). Substantial role of macroalgae in marine carbon sequestration. Nat. Geosci. 9, 737-742. doi: 10.1038/ngeo2790

Krumhansl, K. A., Lee, J. M., and Scheibling, R. E. (2011). Grazing damage and encrustation by an invasive bryozoan reduce the ability of kelps to withstand breakage by waves. J. Exp. Mar. Biol. Ecol. 407, 12-18. doi: 10.1016/j.jembe. 2011.06.033

Kudela, R. M., Seeyave, S., and Cochlan, W. P. (2010). The role of nutrients in regulation and promotion of harmful algal blooms in upwelling systems. Prog. Oceanography 85, 122-135. doi: 10.1016/j.pocean.2010.02.008

Kulk, G., Platt, T., Dingle, J., Jackson, T., Jönsson, B. F., Bouman, H. A., et al. (2020). Primary production, an index of climate change in the ocean: satellite-based estimates over two decades. Remote Sens. 12:826. doi: 10.3390/rs12050826

Legendre, L., Rivkin, R. B., Weinbauer, M. G., Guidi, L., and Uitz, J. (2015). The microbial carbon pump concept: potential biogeochemical significance in the globally changing ocean. Prog. Oceanography 134, 432-450. doi: 10.1016/j. pocean.2015.01.008
Liu, C. X., Zou, D. H., Liu, Z. W., and Ye, C. P. (2020). Ocean warming alters the responses to eutrophication in a commercially farmed seaweed, Gracilariopsis lemaneiformis. Hydrobiologia 847, 879-893. doi: 10.1007/s10750-019-0 4148-2

Lobban, C. S., and Harrison, P. J. (1994). Seaweed Ecology and Physiology. Cambridge: Cambridge University Press.

López-Pérez, A., Guendulain-García, S., Granja-Fernández, R., Hernández-Urraca, V., Galván-Rowland, L., Zepeta-Vilchis, R., et al. (2016). Reef community changes associated with the 2009-2010 El Niño in the Southern Mexican Pacific1. Pacific Sci. 70, 175-190. doi: 10.2984/70.2.4

McCabe, R. M., Hickey, B. M., Kudela, R. M., Lefebvre, K. A., Adams, N. G., Bill, B. D., et al. (2016). An unprecedented coastwide toxic algal bloom linked to anomalous ocean conditions. Geophys. Res. Lett. 43, 10-366.

McPherson, M. L., Finger, D. J. I., Houskeeper, H. F., Bell, T. W., Carr, M. H., Rogers-Bennett, L., et al. (2021). Large-scale shift in the structure of a kelp forest ecosystem co-occurs with an epizootic and marine heatwave. Commun. Biol. 4, $1-9$.

Mertens, N. L., Russell, B. D., and Connell, S. D. (2015). Escaping herbivory: ocean warming as a refuge for primary producers where consumer metabolism and consumption cannot pursue. Oecologia 179, 1223-1229. doi: 10.1007/s00442015-3438-8

Montie, S., Thomsen, M. S., Rack, W., and Broady, P. A. (2020). Extreme summer marine heatwaves increase chlorophyll a in the Southern Ocean. Antarctic Sci. 32, 508-509. doi: 10.1017/s0954102020000401

Nepper-Davidsen, J., Andersen, D. T., and Pedersen, M. F. (2019). Exposure to simulated heatwave scenarios causes long-term reductions in performance in Saccharina latissima. Mar. Ecol. Prog. Ser. 630, 25-39. doi: 10.3354/meps13133 NOAA (2021). https://www.co2.earth/. USA.

Oliver, E. C., Benthuysen, J. A., Darmaraki, S., Donat, M. G., Hobday, A. J., Holbrook, N. J., et al. (2020). Marine heatwaves. Ann. Rev. Mar. Sci. 13, 227-238.

Oliver, E. C., Donat, M. G., Burrows, M. T., Moore, P. J., Smale, D. A., Alexander, L. V., et al. (2018). Longer and more frequent marine heatwaves over the past century. Nat. Commun. 9:1324.

Ortega, A., Geraldi, N. R., Alam, I., Kamau, A. A., Acinas, S. G., Logares, R., et al. (2019). Important contribution of macroalgae to oceanic carbon sequestration. Nat. Geosci. 12, 748-754. doi: 10.1038/s41561-019-0421-8

Pearce, A. F., Lenanton, R. C., Jackson, G., Moore, J., Feng, M., and Gaughan, D. (2011). The "marine heat wave" off Western Australia during the summer of 2010/11. Western Australia: Department of Fisheries, 40. Fisheries Research Report No. 222.

Philander, S. G. H. (1983). El Niño Southern Oscillation phenomena. Nature 302, 295-301. doi: 10.1038/302295a0

Raven, J. A. (2017). The possible roles of algae in restricting the increase in atmospheric CO2 and global temperature. Eur. J. Phycol. 52, 506-522. doi: 10.1080/09670262.2017.1362593

Reed, D., Washburn, L., Rassweiler, A., Miller, R., Bell, T., and Harrer, S. (2016). Extreme warming challenges sentinel status of kelp forests as indicators of climate change. Nat. Commun. 7:13757.

Roberts, S. D., Van Ruth, P., Wilkinson, C., Bastianello, S. B., and Bansemer, M. S. (2019). Marine heatwave, harmful algae blooms and an extensive fish kill event during 2013 in South Australia. Front. Mar. Sci. 6:610. doi: 10.3389/fmars.2019. 00610

Ryan, J. P., Kudela, R. M., Birch, J. M., Blum, M., Bowers, H. A., Chavez, F. P., et al. (2017). Causality of an extreme harmful algal bloom in Monterey Bay, California, during the 2014-2016 northeast Pacific warm anomaly. Geophys. Res. Lett. 44, 5571-5579. doi: 10.1002/2017gl072637

Saha, M., Barboza, F. R., Somerfield, P. J., Al-Janabi, B., Beck, M., Brakel, J., et al. (2020). Response of foundation macrophytes to near-natural simulated marine heatwaves. Global Change Biol. 26, 417-430. doi: 10.1111/gcb.14801

Sakamoto, S., Lim, W. A., Lu, D. D., Dai, X. F., Orlova, T., and Iwataki, M. (2021). Harmful algal blooms and associated fisheries damage in East Asia: current status and trends in China, Japan, Korea and Russia. Harmful Algae 102:101787. doi: 10.1016/j.hal.2020.101787

Santos, I. R., Burdige, D. J., Jennerjahn, T. C., Bouillon, S., Cabral, A., Serrano, O., et al. (2021). The renaissance of Odum's outwelling hypothesis in 'Blue Carbon' science. Estuarine Coastal Shelf Sci. 255:107361. doi: 10.1016/j.ecss.2021.1 07361 
Scannell, H. A., Pershing, A. J., Alexander, M. A., Thomas, A. C., and Mills, K. E. (2016). Frequency of marine heatwaves in the North Atlantic and North Pacific since 1950. Geophys. Res. Lett. 43, 2069-2076. doi: 10.1002/2015gl067308

Schippers, P., Lürling, M., and Scheffer, M. (2004). Increase of atmospheric CO2 promotes phytoplankton productivity. Ecol. Lett. 7, 446-451. doi: 10.1111/j. 1461-0248.2004.00597.x

Schlüter, L., Lohbeck, K. T., Gutowska, M. A., Gröger, J. P., Riebesell, U., and Reusch, T. B. (2014). Adaptation of a globally important coccolithophore to ocean warming and acidification. Nat. Climate Change 4, 1024-1030. doi: 10.1038/nclimate2379

Sen Gupta, A., Thomsen, M., Benthuysen, J. A., Hobday, A. J., Oliver, E., Alexander, L. V., et al. (2020). Drivers and impacts of the most extreme marine heatwaves events. Sci. Rep. 10:19359.

Short, J., Foster, T., Falter, J., Kendrick, G. A., and McCulloch, M. T. (2015). Crustose coralline algal growth, calcification and mortality following a marine heatwave in Western Australia. Continental Shelf Res. 106, 38-44. doi: 10.1016/ j.csr.2015.07.003

Simonson, E. J., Metaxas, A., and Scheibling, R. E. (2015). Kelp in hot water: effects of warming seawater temperature on kelp quality as a food source and settlement substrate. Mar. Ecol. Prog. Ser. 537, 105-119. doi: 10.3354/ meps 11421

Smale, D. A., and Wernberg, T. (2013). Extreme climatic event drives range contraction of a habitat-forming species. Proc. R. Soc. B-Biological Sci. 280:20122829. doi: 10.1098/rspb.2012.2829

Smayda, T. J. (2010). Adaptations and selection of harmful and other dinoflagellate species in upwelling systems 2. motility and migratory behaviour. Prog. Oceanography 85, 71-91. doi: 10.1016/j.pocean.2010.02.005

Smetacek, V., and Zingone, A. (2013). Green and golden seaweed tides on the rise. Nature 504, 84-88. doi: 10.1038/nature12860

Straub, S. C., Wernberg, T., Thomsen, M. S., Moore, P. J., Burrows, M. T., Harvey, B. P., et al. (2019). Resistance, extinction, and everything in between-the diverse responses of seaweeds to marine heatwaves. Front. Mar. Sci. 6:763. doi: 10.3389/ fmars.2019.00763

Sullaway, G. H., and Edwards, M. S. (2020). Impacts of the non-native alga Sargassum horneri on benthic community production in a California kelp forest. Mar. Ecol. Prog. Ser. 637, 45-57. doi: 10.3354/meps13231

Sun, X., Wu, M., Xing, Q., Song, X., Zhao, D., Han, Q., et al. (2018). Spatiotemporal patterns of Ulva prolifera blooms and the corresponding influence on chlorophyll-a concentration in the Southern Yellow Sea, China. Sci. Total Environ. 640, 807-820.

Tait, L. W., South, P. M., Lilley, S. A., Thomsen, M. S., and Schiel, D. R. (2015). Assemblage and understory carbon production of native and invasive canopyforming macroalgae. J. Exp. Mar. Biol. Ecol. 469, 10-17. doi: 10.1016/j.jembe. 2015.04.007

Tang, Y. Z., and Gobler, C. J. (2011). The green macroalga, Ulva lactuca, inhibits the growth of seven common harmful algal bloom species via allelopathy. Harmful Algae 10, 480-488. doi: 10.1016/j.hal.2011.03.003

Tang, Y. Z., Ma, Z. P., Hu, Z. X., Deng, Y. Y., Yang, A. A., Lin, S. H., et al. (2019). 3,000 km and 1,500-year presence of Aureococcus anophagefferens reveals indigenous origin of brown tides in China. Mol. Ecol. 28, 4065-4076. doi: $10.1111 / \mathrm{mec} .15196$

Thomsen, M. S., Mondardini, L., Alestra, T., Gerrity, S., Tait, L., South, P. M., et al. (2019). Local extinction of bull kelp (Durvillaea spp.) due to a marine heatwave. Front. Mar. Sci. 6:84. doi: 10.3389/fmars.2019.00084
Tozzi, S., Schofield, O., and Falkowski, P. (2004). Historical climate change and ocean turbulence as selective agents for two key phytoplankton functional groups. Mar. Ecol. Prog. Ser. 274, 123-132. doi: 10.3354/meps2 74123

Trainer, V. L., Moore, S. K., Hallegraeff, G., Kudela, R. M., Clement, A., Mardones, J. I., et al. (2020). Pelagic harmful algal blooms and climate change: lessons from nature's experiments with extremes. Harmful Algae 91:101591. doi: 10.1016/j. hal.2019.03.009

Weitzman, B., Konar, B., Iken, K., Coletti, H., Monson, D., Suryan, R., et al. (2021). Changes in rocky intertidal community structure during a marine heatwave in the northern Gulf of Alaska. Front. Mar. Sci. 8:556820. doi: 10.3389/fmars.2021. 556820

Wernberg, T., Bennett, S., Babcock, R. C., de Bettignies, T., Cure, K., Depczynski, M., et al. (2016). Climate-driven regime shift of a temperate marine ecosystem. Science 353, 169-172. doi: 10.1126/science.aad8745

Wernberg, T., Krumhansl, K., Filbee-Dexter, K., and Pedersen, M. F. (2018). "Status and trends for the world's kelp forests," in World Seas: An Environmental Evaluation, Vol III: Ecological Issues and Environmental Impacts, ed. C. Sheppard (Amsterdam: Elsevier), 57-78. doi: 10.1016/b978-0-12-805052-1. 00003-6

Winder, M., and Sommer, U. (2012). Phytoplankton response to a changing climate. Hydrobiologia 698, 5-16. doi: 10.1007/978-94-007-5 790-5 2

Xiao, X., Agusti, S., Lin, F., Li, K., Pan, Y. R., Yu, Y., et al. (2017). Nutrient removal from Chinese coastal waters by large-scale seaweed aquaculture. Sci. Rep. 7:46613.

Xu, Z. G., Gao, G., Xu, J. T., and Wu, H. Y. (2017). Physiological response of a golden tide alga (Sargassum muticum) to the interaction of ocean acidification and phosphorus enrichment. Biogeosciences 14, 671-681. doi: 10.5194/bg-14671-2017

Zarco-Perello, S., Wernberg, T., Langlois, T. J., and Vanderklift, M. A. (2017). Tropicalization strengthens consumer pressure on habitat-forming seaweeds. Sci. Rep. 7:820.

Zohdi, E., and Abbaspour, M. (2019). Harmful algal blooms (red tide): a review of causes, impacts and approaches to monitoring and prediction. Int. J. Environ. Sci. Technol. 16, 1789-1806. doi: 10.1007/s13762-01 8-2108-x

Conflict of Interest: The authors declare that the research was conducted in the absence of any commercial or financial relationships that could be construed as a potential conflict of interest.

Publisher's Note: All claims expressed in this article are solely those of the authors and do not necessarily represent those of their affiliated organizations, or those of the publisher, the editors and the reviewers. Any product that may be evaluated in this article, or claim that may be made by its manufacturer, is not guaranteed or endorsed by the publisher.

Copyright (c) 2021 Gao, Zhao, Jiang and Gao. This is an open-access article distributed under the terms of the Creative Commons Attribution License (CC BY). The use, distribution or reproduction in other forums is permitted, provided the original author(s) and the copyright owner(s) are credited and that the original publication in this journal is cited, in accordance with accepted academic practice. No use, distribution or reproduction is permitted which does not comply with these terms. 